\title{
Quantitative Analysis of Crisis: Crisis Identification and Causality
}

\author{
Yoichiro ISHIHARA ${ }^{\mathrm{i}}$ \\ World Bank \\ Email: yishihara@worldbank.org
}

\begin{abstract}
Studies use different conceptual and operational definitions of crises. The different crisis identifications can lead to inconsistent conclusions and policy formulation even if the same analytical framework is applied. Also, most studies focus on only a few types of crises. This narrow focus on crises may not capture the multidimensionality of crises. Seven crisis types are analyzed; namely, (i) liquidity type banking crises, (ii) solvency type banking crises, (iii) balance of payments crises, (iv) currency crises, (v) debt crises, (vi) growth rate crises and (vii) financial crises. Crisis data are collected from 15 emerging economies in 1980-2002 on a quarterly basis. The crisis identification exercise finds that multidimensionality in which different crisis types occur in short-periods is one of the most important characteristics of recent crises. Further, Granger causality tests in five Asian economies (Indonesia, the Republic of Korea, Malaysia, the Philippines and Thailand) find that currency crises tend to trigger other types of crises, and therefore exchange rate management is essential.
\end{abstract}

\section{World Bank Policy Research Working Paper 3598, May 2005}

The Policy Research Working Paper Series disseminates the findings of work in progress to encourage the exchange of ideas about development issues. An objective of the series is to get the findings out quickly, even if the presentations are less than fully polished. The papers carry the names of the authors and should be cited accordingly. The findings, interpretations, and conclusions expressed in this paper are entirely those of the authors. They do not necessarily represent the view of the World Bank, its Executive Directors, or the countries they represent. Policy Research Working Papers are available online at http://econ.worldbank.org.

\footnotetext{
${ }^{\mathrm{i}}$ Ishihara, World Bank Office Jakarta. ¥Comments from Professor Shigeru Otsubo, Professor Hiroshi Osada and Associate Professor Yumiko Okamoto at the Department of International Development at the Graduate School of International Development at Nagoya University are gratefully acknowledged. Comments on this article should be addressed to Yoichiro Ishihara (yishihara@worldbank.org).
} 


\section{Quantitative Analysis of Crisis : Crisis Identification and Causality}

\section{Introduction}

This paper analyzes crises in emerging economies on a cross-country and time-series basis. Different types of crises across countries and periods are examined using the same approach, which enables us to identify crises objectively and to measure the depth and length of crises consistently.

Most studies focus mainly on a few types of crises such as banking and currency crises for international comparison. However, since the 1990s multi-dimensional crises in which different crisis types acur simultaneously have become more prevalent. Therefore the narrow focus on crisis types may not capture this important aspect of recent crises. In contrast, studies dealing with more than a few types of crises tend to be country specific and qualitative, and not necessarily suitable for international comparison. In addition, most studies use annual data which often cannot adequately capture the rapid developments of different crisis types.

Further, existing studies use different crisis definitions and accordingly they have different crisis identifications. Even if the same analytical framework is applied, the different identifications may lead to contrasting conclusions in crisis related studies. This may in turn lead to inconsistent policy recommendations. Therefore if different crisis types can be compared across countries and periods using the same approach, crises can be more clearly identified and the characteristics of different crises can be better understood.

Seven crisis types in 15 emerging economies between Q1 1980 and Q4 2002 are examined in this paper. As one of the most important common features of crises is an 'abrupt' change in economic indicators, standardized scores are used to identify crisis periods. Then, two sets of rules are applied to identify crisis episodes, which are a core part of crisis periods. As a result 59 crisis episodes are identified. Afterwards, in order to clarify the transmission mechanism between crises, Granger causality tests are conducted for five Asian countries (Indonesia, Korea, Malaysia, the Philippines and Thailand).

\section{Crisis Identification}

\subsection{Literature Review}

There is no consensus on definitions of different types of crises despite their frequency in development economics. While conceptual definitions are generally agreed on, operational definitions are more controversial. A conceptual definition is an entry point for crisis identification or a descriptive expression of a crisis. An operational definition divides crisis and non-crisis periods. Accordingly, it requires an indicator and threshold. The operational definition should of course be consistent with the conceptual definition. Existing studies on crises mainly focus on five crisis types such as balance of payments, banking, currency, debt and financial crises. However, each study uses different conceptual and operational definitions for the same crisis type. As a result, crisis identifications differ in each study, although some of the difference stems from choices of sample periods and countries.

\subsubsection{Balance of Payments Crises}

Balance of payments crises are conceptually defined as 'an abrupt loss of international reserves'. Krugman and Obstfeld (1997, p.504) define balance of payments crises as "a sharp change in official foreign 
reserves s parked by a change in expectations about the future exchange rate." Kaminsky and Reinhart (1998, p.12) define balance of payments crises as "reserves are lost abruptly and currency pegs abandoned." However, an operational definition of balance of payments crises to identify the abrupt loss of reserves is rarely found.

\subsubsection{Banking Crises}

Banking crises are conceptually defined as "a period in which significant segment of the banking system become illiquid or insolvent." (Demirguc-Kunt et al., 2000, p.4) ${ }^{(1)}$ According to this conceptual definition, banking crises possess liquidity and solvency aspects. Further, liquidity crises occur "when a bank cannot honor its immediate contractual obligations to its creditors, even though its net value is positive. That is, it does not have funds to meet the withdrawal of deposits at a given point in time, although over time it would be able to do so." (Kumar, Masson and Miller, 2000, p.4) Solvency crises refer to a situation where "the bank's liabilities exceed its assets in present-value and the bank is effectively bankrupt." (ibid, p.4) In terms of an operational definition there are mainly four approaches such as asset, liability, capital account and government assistance approaches. The asset approach that focuses on the quality of asset and non-performing loans (NPLs) ratio is often used as an indicator (Demirguc-Kunt and Detragiache (1997)). The liability approach focuses on the liability side of banks' balance sheet. The essence of this approach is the incidence of bank runs. Glick and Hutchison (1999, p.8) assert that "most banking problems in recent years are not associated with bank runs (liability side of the balance sheet)..." However recent banking crises in Indonesia in 1998 and in Argentina in 2002 reveal that bank runs are still an important feature. The capital account approach focuses on the capital account of the balance sheet. For example Caprio and Klingebiel (1996, p.2) state that banking crises are "much or all banks' capital being exhausted." And the government assistance approach identifies banking crises as at least one of the policies such as (i) large-scale nationalization of banks, (ii) deposit freezing, (iii) bank closure, and (iv) bank recapitalization is undertaken. Although the liability and government assistance approaches are commonly used, there are few quantitative indicators introduced. Therefore, the actual banking crisis identification depends on which approach is used.

\subsubsection{Currency Crises}

Currency crises are conceptually defined as an abrupt depreciation of the currency. For example, Glick and Hutchison (1999, p.6) define currency crises conceptually as "large changes in some indicators of actual or potential currency values." A critical point on which some studies disagree is whether to include unsuccessful currency attacks. Supporters of the inclusion propose to construct a currency pressure index composed of exchange rates, interest rates and reserves, since they argue that a country can defend currency

crises by increasing interest rates and/or intervening in the markets by selling international reserves. ${ }^{(2)}$ Operationally, the treatment of currency depreciation under hyperinflation is another important issue. Frank and Rose (1996) identify currency crises on an annual basis when a currency depreciates more than 25 percent from the previous year and the depreciation rate should be higher than the previous year by more than 10 percent to exclude currency depreciation associated with hyperinflation. Others (for example, Esquivel and Larrain (1998)) use real exchange rates to exclude the impacts of hyperinflation. Goldfajn and Gupta (1999, pp.5-6) attempt to distinguish currency crises by measuring the departure of the actual real exchange rate from an estimated equilibrium real exchange rate. The authors use a Hodrick-Prescott filtered series to measure the deviation from the actual exchange rates. 


\subsubsection{Debt Crises}

The widely accepted conceptual definition of external debt crises is as "inability of debtors to make timely payments of interests and principals." (Dornbusch, 1989, p.301) There are few challenges on this conceptual definition. ${ }^{(3)}$ However, operationally, it is difficult how to define 'inability'. There are two approaches. One is actual defaults or near default events. The other is the use of debt indicators. The 1980s witnessed external debt crises in Latin American countries. For example in 1982 Mexico suspended its debt service and in 1987 Brazil suspended its debt service (Thirlwall, 1999) as Argentina did in 2002. However, even though these countries declared default, whether they did not have the ability or intention to pay is not clear. The Non-Aligned Movement Ad Hoc Advisory Group of Experts on Debt (1994, p.11) states that "arrears are a key indicator of the intensity of a developing country's debt burden, because of their undisputed nature as actual facts" and further defines that "developing countries face serious debt servicing difficulties with arrears in excess of 20 percent of scheduled debt service." Detragiache and Spilimbergo (2001, p.6) define debt crises as if either or both of the following conditions occur: (i) there are arrears of principal or interest on external obligations towards commercial creditors (banks or bondholders) of more than 5 percent of total commercial debt outstanding; (ii) there is a rescheduling or debt restructuring agreement with commercial creditors as listed in the GDF [Global Development Finance published by World Bank]. This 5 percent threshold is to rule out cases in which the share of debt in default is negligible, while the second criterion is to include countries that are not technically in arrears because they reschedule or restructure their obligations before defaulting. There are numerous external debt indicators such as the debt to GDP ratio, the debt to exports ratio and the debt service ratio. Ajayi (1997, p.9) asserts that debt burden and the servicing capacity of external debt are shown primary by five indicators: (i) the debt to exports ratio, (ii) the debt to GNP ratio, (iii) the debt service to exports ratio, (iv) the interest to exports ratio, and (v) the interest to GNP ratio. Among the five indicators, the author views that the debt service to exports ratio as well as the debt service to GNP (GDP) ratio are useful indices of solvency.

\subsubsection{Financial Crises}

Despite its frequency especially in the late 1990s, there is still no consensus on a conceptual definition on financial crises. Accordingly there are few operational definitions. Some studies argue that financial crises are a combination of different types of crises. For example, Aziz et al. (2000, p.5) explain that "financial crisis may be grouped into three broad categories: currency crises, banking crises, and foreign debt crises." On the other hand, others define financial crises as "potentially severe disruptions of financial markets that, by impairing markets ability to function effectively, can have large adverse effects on the real economy" (IMF, 1998, p.75) and "a nonlinear disruption to financial markets..." (Mishkin, 1997, p.38) Caprio (1998, p.3) argues that "financial crises regularly originate in or induce insolvency in the banking system, and feature a collapse in asset prices, most often in equity and securities markets" but the same author further asserts (ibid, p.4) "a financial crisis usually involves a corporate debt problem in the nonblank financial sector, in other words, banks and other intermediaries usually do not get into trouble if borrowers can easily service their debt." Sachs and Woo (2000, p.13) state that "financial crises are characterized by an abrupt and significant shift from net capital inflows to net capital outflow from one year to the next." 
The differences in crisis identifications mainly come from three sources. First, if a conceptual definition differs, the resulting operational definition is likely to differ as well. As a result, the operational definition inevitably leads to different crisis identifications. Second, many studies especially banking cris is studies directly refer to other studies' crisis identifications or just combine different studies' identifications regardless of the differences in conceptual definitions. For example, Hutchison and Neuberger (2002, p.9) combine crisis episodes of Caprio and Klingebiel (1996) and Dermirguc-Kunt and Detragiache (1998), although these two articles use different operational definitions. Third, data availability and frequencies may cause different identifications of crises. Most studies use annual data mainly due to data availability. However the annual data cannot identify crises that start and end within the same year.

A comparison of existing banking crisis studies clearly shows the crisis identification problem resulting from different conceptual definitions. Thirteen banking crisis studies are reviewed to check whether there are different banking crisis definitions. Not only are there enormous differences between the operational definitions, seven studies do not even explain the operational definitions (Table 1). For example, regarding Indonesia's banking crisis identification in the early 1990s, while most studies agree on banking crisis identification in 1992 and 1994, only five out of 13 studies identify 1993 as a crisis period. This ambiguity of crisis identification may cause serious problems. For example, in the early warning system studies in which crises are dependent variables, different crisis identifications may lead to different conclusions even if the same analytical framework is applied. Therefore, each type of crisis should be identified using clear conceptual and operational definitions with the same threshold.

Table 1: Banking Crisis Definition of Existing Studies

\begin{tabular}{|c|c|c|c|c|c|}
\hline & Liability & Asset & Capital & $\begin{array}{c}\text { Gov't } \\
\text { assistance }\end{array}$ & Total \\
\hline Mehrez and Kaufman (2000) & $x$ & $x$ & $x$ & $x$ & 0 \\
\hline Kaminsky (1999) & $\times$ & $\times$ & $\times$ & $\times$ & 0 \\
\hline Hoggarth, Reis and Saporta (2002) & $?$ & $\times$ & $?$ & $?$ & 3 \\
\hline Honohan and Klingebiel (2002) & $x$ & $x$ & $x$ & $x$ & 0 \\
\hline Demirguc-Kunt and Detragiache (1997) & $?$ & $?$ & $x$ & $?$ & 3 \\
\hline Hardy and Pazarbasioglu (1998) & $x$ & $\times$ & $x$ & $\times$ & 0 \\
\hline Glick and Hutchison (1999) & $x$ & $x$ & $x$ & $x$ & 0 \\
\hline Kaminsky and Reinhart (1998) & $?$ & $?$ & $\times$ & $?$ & 3 \\
\hline Demirguc-Kunt, Detragiache and Gupta (2000) & $?$ & $?$ & $\times$ & $?$ & 3 \\
\hline Boyd, Gomis, Kwak, and Smith (2000) & $\times$ & $\times$ & $\times$ & $\times$ & 0 \\
\hline Frydl (1999) & $x$ & $x$ & $\times$ & $x$ & 0 \\
\hline Caprio and Klingebiel (1996) & $x$ & $x$ & $?$ & $x$ & 1 \\
\hline Demirguc-Kunt and Detragiache (2000) & $?$ & $?$ & $x$ & $?$ & 3 \\
\hline Total & 5 & 4 & 2 & 5 & 16 \\
\hline
\end{tabular}

Note: ? denotes operational definition(s) used to identify banking crisis

Source: Author

\subsection{Alternative Crisis Identification Approach}

A conceptual definition should best describe characteristics of crises, and an operational definition identifies crises by using an appropriate indicator and threshold. If the indicator exceeds the threshold this is the start of crises and vice versa. The periods exceeding the threshold are crisis periods and the gap between the threshold and the indicator is a degree of the crisis (Fig. 1). 
If the same threshold is applied to crisis indicators, different crisis types across countries and periods can be compared on the same scale. Then the relationships between crises become clearer and hence better analyzed. There are two approaches to determine the threshold. One approach is to set an absolute level of an indicator, and the other approach is to use a deviation from a trend. The first approach means different thresholds are used for different indicators. For example, if the external debt to GDP ratio exceeds ' $x$ ' percent, it is identified as a debt crisis. The second approach, for example, is that if the external debt to GDP ratio of a certain period, say ' $t$ ', exceeds ' $y$ ' years average by ' $z$ ' times standard deviation, this period is identified as debt crises. The second approach or the deviation from a trend allows comparing various crisis indicators on the same scale. Further, this approach can capture an 'abrupt' change in an indicator which is one of the most important characteristics of crises. In contrast, a drawback of this approach is that it identifies crises regardless of an absolute level.

To measure the deviation from a trend, the first step is to convert indicators into standardized scores. The second step is to compare standardized scores with a common threshold. If standardized scores exceed the threshold in a certain period, this period is identified as a crisis period. This crisis identification method is commonly used to identify currency crises. ${ }^{(4)}$ To calculate a standardized score (Z), first the gap between the value $(\mathrm{X})$ and mean $(\mu)$ is calculated, and then the deviation is divided by the standard deviation (d) (Equation 1).

$$
Z=\frac{X-\mu}{d}
$$

Standardized scores follow normal distribution with mean zero and standard deviation one (Wonnacott and Wonnacott, 1990). Standardized scores show how many times of standard deviations the value is away from the mean. For example, when a standardized score of an indicator is 1.0, this means the indicator is away from the mean by 1.0 standard deviation and the probability of exceeding 1.0 is 15.9 percent. In this article, standardized scores are calculated on a moving average basis so that a change in sample periods does not affect the crisis and non-crisis identification. For example, if a standardized score of period $\left(Z_{t}\right)$ is calculated by an indicator of $\left(X_{t}\right)$, the mean of periods $(1 \ldots t)$, and the standard deviation of periods $(1 \ldots t)$, a standardized score of the next period $\left(\mathrm{Z}_{t+1}\right)$ is calculated by an indicator of $\left(\mathrm{X}_{t+1}\right)$, the mean of periods $(2 \ldots t+1)$, and the standard deviation of periods $(2 \ldots t+1)$.

Choices of sample periods for standardized scores and the threshold are arbitrary. In currency crisis 
studies adopting this methodology, the threshold ranges from 1.5 to 3.0 and few logical explanations on the choices of thresholds are found. The lower the threshold is the more crisis periods are identified. This analysis uses 2.0 as the threshold, since this is about an average of currency crisis studies, and then the probability to exceed 2.0 is 2.5 percent. Regarding sample periods, this analysis uses five years so that the number of sample data becomes 20 on a quarterly basis, since the minimum number of data for an analysis is 20 as a rule of thumb.

As shows in Fig. 1, the degree of crisis is measured by the combination of the length of crisis periods and depths. The depth of a crisis in period $(t)$ is the standardized score of period $(t)$ when exceeding threshold (2.0). As such, the total degree of a crisis episode is measured by the following equation (2), and two sets of conditions to identify a crisis episode is further explained in section 2.4 .

$$
\sum_{i=1}^{m} \sum_{t=1}^{n} a_{i t}
$$

where $\mathrm{a}_{i t}$ is a crisis depth of $(m)$ different type of crises $(i>2.0)$ at the period of $t$ and $n$ is the length of a crisis episode. Equation (2) shows that the degree of a crisis episode is determined by the length, the depth and the number of crisis types involved.

\subsection{Multidimensional Aspects of Crises}

One of the most important characteristics of recent crises is multidimensionality in which several types of crises occur simultaneously and/or one type of crises affects other crisis types within a short period. Although most crisis studies focus on five types of crises such as banking, balance of payments, currency, debt and financial crises, few studies handle all fives types of crises together and existing studies miss other important types of crises. This article includes growth rate crises, and banking crises is divided into liquidity type banking crises and solvency type banking crises. Accordingly this article deals with seven types of crises. A change in growth rates affects other crisis types and therefore growth rate crises are treated equally to other types of crises, although some studies (for example, Gupta, Mishra and Sahay (2001), and Aziz et al (2000, p.23), Hutchison and Neuberger (2002)) use growth rates to measure the costs of other types of crises. The literature review shows existing crisis studies are ambiguous about conceptual and operational definitions of crises. Thereby the definitions should be clarified. Table 2 shows the summary result of the clarification. 
Table 2: Summary of Conceptual and Operational Definitions of Different Types of Crises

\begin{tabular}{|c|c|c|}
\hline Crisis Type & Conceptual Definition & Operational Definition \\
\hline Banking (Liquidity) & $\begin{array}{l}\text { A bank cannot honor its immediate } \\
\text { contractual obligations }\end{array}$ & Demand deposits to total assets ratio \\
\hline Banking (Solvency) & The bank's liabilities exceed its assets & Capital accounts to total assets ratio \\
\hline "Balance of Payments & An abrupt loss of international reserves & $\begin{array}{l}\text { Year-on-year growth rates of gross } \\
\text { international reserves }\end{array}$ \\
\hline Currency & An abrupt depreciation of the currency & $\begin{array}{l}\text { Nominal exchange rates against the US } \\
\text { dollar }\end{array}$ \\
\hline External Debt & $\begin{array}{l}\text { Inability of debtors to make timely } \\
\text { payments of interests and principals }\end{array}$ & External debt to exports ratio \\
\hline Growth Rate & A sharp decline in real outputs & Year-on-year growth rate of GDP \\
\hline Financial & $\begin{array}{l}\text { An abrupt loss of confidence in a country's } \\
\text { financial sector }\end{array}$ & Capital flight \\
\hline
\end{tabular}

Note: Conceptual definition is descriptive expression of crisis, while operational definition is an indicator to divide crisis and non-crisis periods

Source: Author

\subsubsection{Balance of Payments Crises}

An operational definition of balance of payments crises is rarely found, although most studies agree on the conceptual definition, which is an abrupt loss of international reserves. Several studies (for example, IMF (2000)) examine reserve adequacy levels by using, for example, the reserve to imports ratio (as months of imports) and the short-term external debt to reserve ratio from the viewpoint of the correlation with crisis incidences. However, these ratios do not necessarily fit the conceptual definitions, since these ratios show adequate levels of reserves rather than balance of payments crises per se. Since the essence of balance of payments crises is a decline in reserves, year-on-year growth rates of gross international reserves can be used as an indicator in order to avoid seasonal fluctuations. ${ }^{(5)}$

\subsubsection{Banking Crises}

Banking crises can be divided into liquidity and solvency crises. As the essence of liquidity type banking crises is bank runs, deposit figures especially demand deposits seem to be an appropriate indicator. Demand deposits are more suitable than time deposits, since time deposits are tied in certain periods and difficult to cancel before maturity. Therefore, time deposits may not properly capture bank run situations. In order to measure a solvency problem of the banking system, capital figures are used as an indicator. Demand deposits and capital account figures are adjusted by the ratio in total assets. This is because absolute levels or growth rates in local currencies are distorted when banking crises are associated with currency crises. Although BIS (Bank for International Settlement) own capital ratio is widely used to measure the healthiness of the banking system, data is difficult to obtain on a timely basis and time -series data is mostly unavailable in developing countries.

\subsubsection{Currency Crises}

The conceptual definition of currency crises is generally agreed, which is an abrupt depreciation of the currency, though there are two issues such as whether to include unsuccessful currency attacks and whether to choose nominal or real exchange rates. The supporters of the inclusion of unsuccessful currency attacks propose to construct a currency pressure index composed of exchange rates, interest rates and international 
reserves. However, the supporters do not provide any logical explanations on the inclusion, and the change in international reserves is the concept of balance of payments crises rather than currency crises. Several currency crisis studies mix up balance of payments crises with currency crises. It seems more appropriate to use only successful currency attacks. Therefore only exchange rates should be used as an indicator. ${ }^{(6)}$ In relation to the second issue, following the conceptual definition, nominal exchange rates are a suitable indicator regardless of the reasons behind the depreciation such as hyperinflation, political situation and macroeconomic conditions. ${ }^{(7)}$ At the same time, real exchange rates are informative as the comparison between nominal and real exchange rates can be a clue for the cause of depreciation.

\subsubsection{Debt Crises}

Finding an indicator fully compatible with the conceptual definition of external debt crises, which is inability to service debts, is difficult. Debt related indicators show the severity of debt burden rather than inability to service debts. Paris Club debt rescheduling and/or debt reduction are implemented when a country faces external debt repayments difficulties. However, Paris Club deals with only bilateral public debt rather than whole external debt, and sometimes terms of rescheduling and/or debt reduction are politically determined. Therefore the incidences of Paris Club are not necessarily suitable to identify debt crises.

Consequently, the debt burden indicators are used as a proxy for a debt crisis indicator. Among numerous debt indicators, the IMF (2000, p.3 and p.26) states that the external debt to exports ratio is an especially useful indicator of trends in debt and repayment capacity, since the debt to exports ratio is less volatile than the debt to GDP ratio. While both denominator and numerator are measured in the US dollar for the debt to exports ratio, GDP data are basically on a local currency basis and then converted to the US dollar for the debt to GDP ratio. In this sense, the debt to GDP ratio may fluctuate more than the debt to exports ratio when exchange rates are unstable. In order to verify whether the debt to exports ratio is less

volatile than the debt to GDP ratio, the standard deviation of two indicators of fifteen countries ${ }^{(8)}$ are calculated between Q1 1980 and Q4 2002 depending on data availability. In eleven countries out of fifteen, the debt to GDP ratio is more volatile than the debt to exports ratio. Although arrears are one of the key indicators of debt burdens (Non-Aligned Movement Ad Hoc Advisory Group of Experts on Debt (1994), Detragiache and Spilimbergo (2001)), data on arrears are difficult to obtain on a quarterly basis.

\subsubsection{Growth Rate Crises}

Conceptual and operational definitions of growth rate crises are rarely found in various studies, although as a rule of thumb NBER (National Bureau of Economic Research) defines a US recession when seasonally adjusted quarterly growth rates are negative for two straight quarters. Bruno (1996, p.1) defines growth crises as "at least three consecutive years of negative growth (cumulating in a drop in growth of at least nine percent)." Here, conceptually growth rate crises can be defined as a sharp decline in real outputs. Operationally real economic growth rates on a year-on-year basis can be used as an indicator, since seasonally adjusted figures are not often available in emerging economies.

\subsubsection{Financial Crises}

There is no consensus on conceptual and operational definitions of financial crises. However from various studies, the essence of financial crises is 'an abrupt loss of confidence in a country's financial sector'. When a country faces a loss of confidence in its financial sector, financial resources abruptly attempt to flee 
from the country (Sachs and Woo, 2000). This tendency should be more pronounced in private capital rather than public capital, as public capital often flows into a country in the form of international rescue package when a country faces financial crises. In this sense, operationally, capital flight statistics can be used as an indicator. The core of calculating capital flight is net errors and omissions plus non-FDI net private flows in balance of payments (Loungani and Mauro, 2001). One issue is whether to include current transfer in the current account, since this item includes private remittance (Caves, Frankel and Jones, 1996). The decision whether to include the current transfer sometimes makes significant differences on the crisis identification.

For example, the inclusion of the current transfer cannot identify the 2001 Argentina as financial crises, ${ }^{(9)}$ while the exclusion identifies the periods as financial crises. As the 2001 Argentina crisis is often characterized as abrupt capital outflows, the current transfer is excluded from capital flight.

\subsection{Data and Methodology}

The main data sources are the IMF's International Financial Statistics (IFS), the World Bank's Global Development Finance (GDF), World Development Indicators (WDI) and CEIC Asian economic database. Seven crisis types (liquidity type banking, solvency type banking, balance of payments, currency, debt, growth rate and financial crises) in 15 emerging economies between Q1 1980 and Q4 2002 are examined on a quarterly basis based on the operational definitions. The fifteen countries are selected based on regional diversification, frequencies in appearing in existing crisis studies and data availability. These countries are: five East Asian (Indonesia, Korea, Malaysia, the Philippines and Thailand), one European (Turkey), six Latin American (Argentina, Brazil, Colombia, Mexico, Uruguay and Venezuela), two South Asian (India and Sri Lanka), and one African (Kenya).

Data processing and crisis period identification follow four steps:

(i) Choose an indicator for each crisis type;

(ii) Standardize indicators on a five years moving average basis;

(iii) Compare standardized scores with the crisis threshold (-2.0);

(iv) Identify crisis periods if standardized scores exceed the threshold.

These four steps enable us to identify the periods experiencing crises. Crisis period identification is useful for detailed analysis of crises. However, at the same time, the crisis period identification captures spurious signals of the start and end of crises. Then after identifying crisis periods, crisis episodes, which are the core part of crises, are identified using two sets of conditions. The first condition is that there should be at least two types of crises in the same period to pinpoint the start of the crisis episodes. This condition is set to exclude spurious signals of the start of the crisis episodes. As such, all periods with more than two crisis types are included in crisis episodes. The second condition is window periods, and this article sets three quarters window periods based on existing crisis studies. When the period gap between two crisis episodes are less or equal to three quarters, these three quarters are also included in one crisis episode even if these periods has at most one crisis type. This condition is set to exclude spurious signals of the end of the crisis episodes.

Fig. 2 illustrates the relationship between crisis periods and crisis episodes with the symbol (?) denote crisis periods. In period (A), only liquidity type banking crises are identified and therefore this period is not identified as the start of a crisis episode. On the other hand, period $(\mathrm{C})$, period $(\mathrm{G})$ and period $(\mathrm{L})$ has more 
than two types of crises in one period, and therefore these periods are included in a crisis episode. Although period (D), period (E) and period (F) has less or equal to one crisis identification in one period, the gap between period $(C)$ and period $(\mathrm{G})$ is less or equal to three quarters. Then, period (D), period (E) and period (F) are included in one crisis episode together with period $(\mathrm{C})$ and period $(\mathrm{G})$. On the other hand, the gap between period $(\mathrm{G})$ and period $(\mathrm{L})$ is four periods and then the second condition is not met. Therefore, period (L) is recognized as a different crisis episode.

Fig. 2: Examples of the Relationship between Crisis Period and Crisis Episode Identifications

\begin{tabular}{|c|c|c|c|c|c|c|c|c|c|c|c|c|c|}
\hline Period & A & B & C & D & $\mathrm{E}$ & $\mathrm{F}$ & G & $\mathrm{H}$ & I & $\mathrm{J}$ & $\mathrm{K}$ & $\mathrm{L}$ & $\bar{M}$ \\
\hline Liquidity type banking crises & $?$ & & & & & & & & & & & & \\
\hline Solvency type banking crises & & & $?$ & & & & & & & & & $?$ & \\
\hline Balance of payments crises & & & & & $?$ & & $?$ & & & & & & \\
\hline Currency crises & & & $?$ & & & & & & & $?$ & & & \\
\hline Debt crises & & & & & & & $?$ & & & & & & $?$ \\
\hline Growth rate crises & & & & $?$ & & & & & & & & & \\
\hline Financial crises & & & & & & & $?$ & & & & & $?$ & \\
\hline Crisis episode & $x$ & $x$ & $?$ & $?$ & $?$ & $?$ & $?$ & $x$ & $x$ & $x$ & $x$ & $?$ & $x$ \\
\hline
\end{tabular}

Indicators are derived from the following sources.

- Liquidity type banking crises (demand deposits to total assets ratio): IFS line 24 divided by the sum of IFS line 24-27;

- Solvency type banking crises (capital account to total assets ratio): IFS line 27A divided by the sum of IFS line 24-27;

- Balance of payments crises (year-on-year growth rates of gross international reserves): total reserves minus gold (IFS line 1L.d);

- Currency crises (end of period nominal exchange rates against the US dollar): IFS line ae;

- Debt crises (external debt outstanding to exports ratio): external debt outstanding data is obtained from CEIC data base, countries' publications and GDF, and outstanding is divided by IFS line 70;

- Growth rate crises (year-on-year real growth rates): Data is obtained from CEIC data base, countries' publications and interpolated WDI (World Bank's World Development Indicators) data if quarterly data is unavailable;

- $\quad$ Financial cris es (capital flights): IFS line 78 BC (capital account), line 78 BJ (financial account), line 78 CA (net errors and omissions) minus line 78 BD-E (FDI), line 78 BP-BT (government other investments).

\subsection{Result}

This exercise produces two sets of crisis identifications: crisis period and crisis episode. The four steps identify which quarters experience what types of crises, and the two crisis episode conditions are applied to identify crisis episodes. As a result, eight hundred twenty-seven crisis periods and fifty-nine crisis episodes are identified in fifteen emerging economies between Q1 1980 and Q4 2002. There are three dimensions to observe the results, namely country, crisis type and period. 


\subsubsection{Country}

Each country has contrasting features (Table 3). In terms of crisis episodes, total number of crisis episodes is 59 or 3.9 on average. While Turkey has seven crisis episodes, Korea and the Philippines have only two episodes. The total length of crisis episode in Colombia and Turkey is twenty quarters, while it is seven in Malaysia. In Colombia and Turkey, the ratio of crisis episode length to total sample periods is 22 percent or these countries have crisis episodes almost one-fifth of sample periods on average. The total degree of crisis (measured by number of crisis, depth and length) also considerably varies across countries. The total crisis degree of Argentina exceeds one hundred, while that of India is only forty-one. The Philippine's case is unique, since the country has only two crisis episodes but at the same time total degree of the crisis is the second highest in the sample countries, which makes the average degree of one crisis (-49) considerably high.

In terms of crisis periods, differences in countries are less obvious than crisis episodes in some countries. For example, Brazil (76) has almost identical number of crisis periods to Argentina (74), and total degree is higher in Brazil than Argentina, which is a sharp contrast with crisis episodes. This means Brazil has many crisis periods which are not included in crisis episodes. In Brazil, between 1980 and 1994, most periods are identified as currency crisis periods, however currency crisis periods were not accompanied by other types of crises in most periods.

Table 3: Crisis Identification on a Country Basis in Q1 1980-Q4 2002

\begin{tabular}{|c|c|c|c|c|c|c|c|c|c|}
\hline & \multicolumn{4}{|c|}{ Crisis Periods (Quarters) } & \multicolumn{5}{|c|}{ Crisis Episodes } \\
\hline & $\begin{array}{c}\text { No. of } \\
\text { quarters }\end{array}$ & $\begin{array}{l}\text { Ratio in } \\
\text { samples }\end{array}$ & $\begin{array}{c}\text { Total } \\
\text { degree }\end{array}$ & $\begin{array}{c}\text { Crisis } \\
\text { average }\end{array}$ & Number & $\begin{array}{l}\text { Length } \\
\text { (quarters) }\end{array}$ & $\begin{array}{l}\text { Ratio in } \\
\text { samples }\end{array}$ & $\begin{array}{c}\text { Total } \\
\text { degree }\end{array}$ & $\begin{array}{l}\text { Episode } \\
\text { average }\end{array}$ \\
\hline Argentina & 74 & $11.6 \%$ & -205 & -2.8 & 6 & 18 & $30.4 \%$ & -101 & -16.8 \\
\hline Brazil & 76 & $11.8 \%$ & -225 & -3.0 & 5 & 14 & $9.8 \%$ & -66 & -13.2 \\
\hline Colombia & 59 & $11.6 \%$ & -132 & -2.2 & 4 & 20 & $21.7 \%$ & -87 & -21.8 \\
\hline India & 46 & $7.2 \%$ & -108 & -2.4 & 4 & 8 & $8.7 \%$ & -41 & -10.3 \\
\hline Indonesia & 42 & $7.2 \%$ & -120 & -2.9 & 2 & 8 & $8.7 \%$ & -72 & -36.0 \\
\hline Kenya & 46 & $8.4 \%$ & -109 & -2.4 & 5 & 15 & $16.3 \%$ & -49 & -9.8 \\
\hline Korea & 40 & $6.2 \%$ & -105 & -2.6 & 2 & 11 & $12.0 \%$ & -74 & -37.0 \\
\hline Malaysia & 32 & $5.8 \%$ & -84 & -2.6 & 4 & 7 & $7.6 \%$ & -53 & -13.3 \\
\hline Mexico & 54 & $8.7 \%$ & -143 & -2.7 & 4 & 13 & $14.1 \%$ & -89 & -22.2 \\
\hline Philippines & 53 & $8.8 \%$ & -137 & -2.6 & 2 & 19 & $20.7 \%$ & -98 & -49.0 \\
\hline Sri Lanka & 37 & $5.9 \%$ & -95 & -2.6 & 3 & 8 & $8.7 \%$ & -51 & -16.9 \\
\hline Thailand & 53 & $8.3 \%$ & -135 & -2.5 & 3 & 12 & $13.0 \%$ & -91 & -30.3 \\
\hline Turkey & 86 & $14.1 \%$ & -203 & -2.4 & 7 & 20 & $21.7 \%$ & -93 & -13.3 \\
\hline Uruguay & 69 & $12.6 \%$ & -166 & -2.4 & 3 & 11 & $12.0 \%$ & -75 & -25.0 \\
\hline Venezuela & 60 & $10.8 \%$ & -157 & -2.6 & 6 & 19 & $20.7 \%$ & -89 & -14.8 \\
\hline Total & 827 & $9.2 \%$ & $-2,121$ & -2.6 & 59 & 208 & $15.1 \%$ & $-1,130$ & -19.2 \\
\hline Average & 55 & - & -141 & - & 3.9 & 13.9 & - & -75 & - \\
\hline
\end{tabular}

The country basis analysis shows that some countries such as the Philippines may have more severe crisis episodes (longer and/or deeper crises) than others. Table 4 provides five selected crisis episodes according to the total degree of cris is. The Philippines' crisis in the early 1980s has the largest degree 
followed by the Indonesia crisis in the late 1990s. The Philippines crisis was lengthy and continued more than three years. In contrast, the peak degree of crisis was not so large compared to other crisis episodes (Fig. 3). The second to fourth ranked crisis episodes are observed during the Asian crisis in the late 1990s. The feature of these crisis episodes is that while the length of crisis was relatively short, peak degree of cris is and accordingly the number of different types of crises at the peak quarter was larger (Fig. 3, Fig. 4).

Table 4: Selected Crisis Episodes

\begin{tabular}{clcccccc}
\hline Rank & \multicolumn{1}{c}{ Country } & Start & End & $\begin{array}{c}\text { Length } \\
\text { (quarters) }\end{array}$ & $\begin{array}{c}\text { Peak crisis } \\
\text { number }\end{array}$ & Peak degree & $\begin{array}{c}\text { Total } \\
\text { degree }\end{array}$ \\
\hline 1 & Philippines & Q3 1981 & Q3 1984 & 13 & 3 & -8.8 & -68.3 \\
2 & Indonesia & Q3 1997 & Q1 1999 & 7 & 6 & -18.9 & -66.7 \\
3 & Korea & Q4 1996 & Q2 1998 & 7 & 5 & -16.7 & -52.2 \\
4 & Thailand & Q1 1997 & Q2 1998 & 6 & 4 & -14.4 & -50.9 \\
5 & Mexico & Q1 1982 & Q1 1983 & 5 & 4 & -11.5 & -44.0 \\
\hline & Episode & - & - & 3.5 & 2.5 & -6.7 & -19.2 \\
& average & - & & & & & \\
\hline
\end{tabular}

Note: Length: total length of a crisis episode; Peak crisis number: Number of crisis types at a peak quarter (maximum seven), Peak degree: the sum of standardized scores exceeding the threshold at the time of peak; Total degree: the sum of standardized scores exceeding the threshold in a crisis episode.

Source: Author

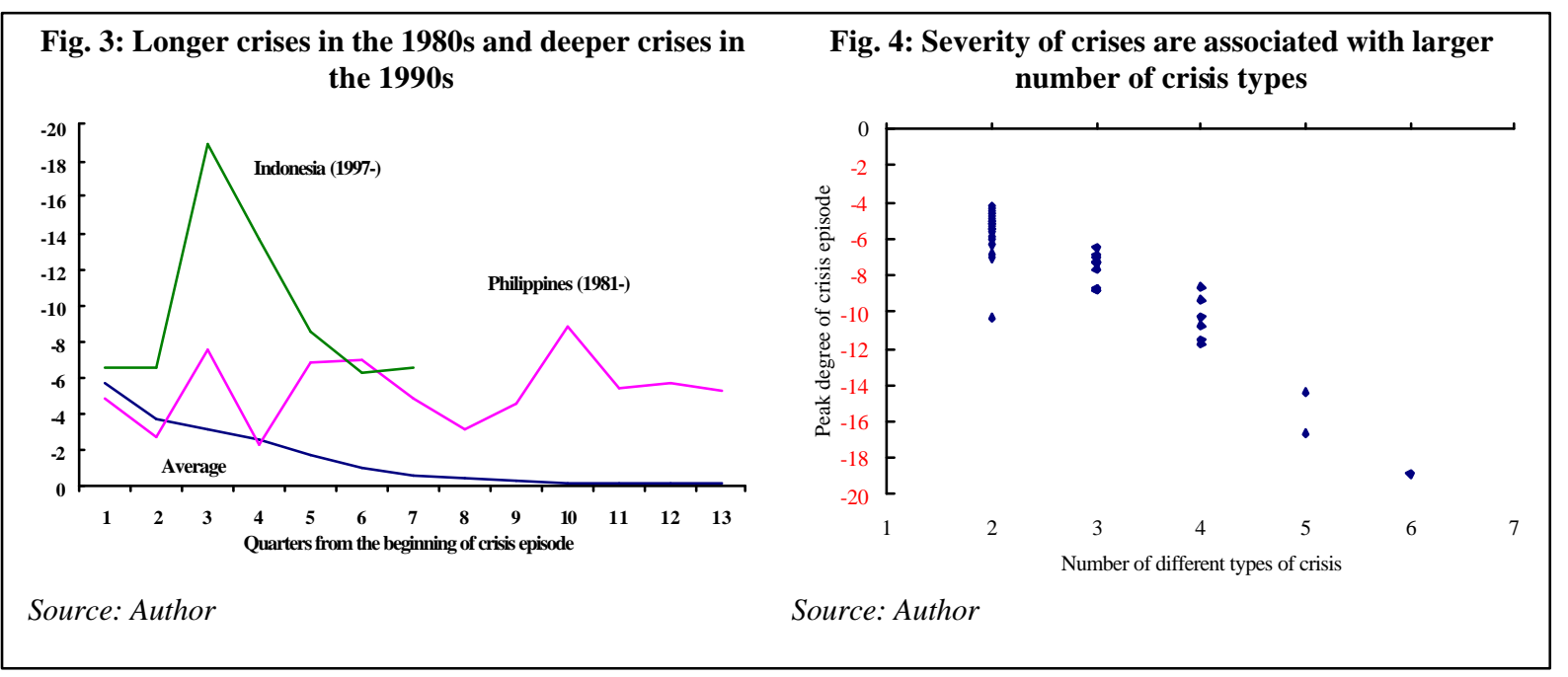

\subsubsection{Crisis}

Currency crises are the dominant crises in seven crisis types throughout the sample periods (Table 5), but the composition of crisis differs in each period. In the crisis period identification, there are 409 quarters experiencing currency crises or 50 percent of total crisis periods (827) followed by 106 growth rate crises or 13 percent of the total. In terms of the ratio in total samples, currency crises account for 29.8 percent, which means on average currency crises are observed in every three quarters. On the other hand, there are only 32 crisis periods with balance of payments crises. The average degree of each type of crises is similar. Financial crises are the deepest (-2.6), while liquidity type banking crises and debt crises are relatively mild $(-2.4)$ compared to other types of crises. 
In terms of crisis episodes, in total 177 crises (cumulative) are involved in 59 crisis episodes. On average, one crisis episode carries three crisis types. There are 50 crisis episodes that include currency crises or 85 percent of crisis episodes are associated with currency crises. Debt crises and financial crises also frequently appear in crisis episodes, as these types of crises are observed in about a half of crisis episodes. On the other hand, balance of payments crises are observed in around 20 percent of total crisis episodes.

Table 5: Crisis Identification on a Crisis Basis in Q1 1980-Q4 2002

\begin{tabular}{|c|c|c|c|c|c|c|c|c|c|}
\hline & \multicolumn{4}{|c|}{ Crisis Periods (Quarters) } & \multicolumn{5}{|c|}{ Crisis Episodes } \\
\hline & $\begin{array}{c}\text { No. of } \\
\text { quarters }\end{array}$ & $\begin{array}{l}\text { Ratio in } \\
\text { samples }\end{array}$ & $\begin{array}{c}\text { Total } \\
\text { degree }\end{array}$ & $\begin{array}{c}\text { Crisis } \\
\text { average }\end{array}$ & $\begin{array}{c}\text { No. of } \\
\text { episodes } \\
1 /\end{array}$ & $\begin{array}{l}\text { Ratio in } \\
\text { episodes }\end{array}$ & $\begin{array}{c}\text { No. of } \\
\text { quarters } \\
2 /\end{array}$ & $\begin{array}{c}\text { Total } \\
\text { degree }\end{array}$ & $\begin{array}{l}\text { Episode } \\
\text { average }\end{array}$ \\
\hline $\begin{array}{c}\text { Banking } \\
\text { (Liquidity) }\end{array}$ & 77 & $5.9 \%$ & -183 & -2.4 & 21 & $38 \%$ & 44 & -103 & -2.3 \\
\hline $\begin{array}{c}\text { Banking } \\
\text { (Solvency) }\end{array}$ & 74 & $5.7 \%$ & -187 & -2.5 & 19 & $33 \%$ & 53 & -136 & -2.6 \\
\hline $\begin{array}{l}\text { Balance of } \\
\text { payments }\end{array}$ & 32 & $2.3 \%$ & -80 & -2.5 & 12 & $21 \%$ & 25 & -63 & -2.4 \\
\hline Currency & 409 & $29.8 \%$ & $-1,080$ & -2.6 & 50 & $85 \%$ & 164 & -451 & -2.8 \\
\hline Debt & 94 & $6.9 \%$ & -226 & -2.4 & 29 & $46 \%$ & 51 & -122 & -2.4 \\
\hline $\begin{array}{l}\text { Growth } \\
\text { rate }\end{array}$ & 106 & $7.7 \%$ & -272 & -2.6 & 30 & $47 \%$ & 75 & -198 & -2.6 \\
\hline Financial & 35 & $4.2 \%$ & -92 & -2.6 & 16 & $29 \%$ & 21 & -57 & -2.8 \\
\hline Total & 825 & $9.2 \%$ & $-2,121$ & -2.6 & 177 & - & 431 & $-1,125$ & -2.6 \\
\hline Average & 118 & - & 303 & - & 3.0 & & 7.3 & & \\
\hline
\end{tabular}

The frequency of each type of crises differs in each period (Table 6, Fig 5). Although currency crises are dominant throughout the periods, their relative frequency declines in the late 1990s. Currency crises account for more than 50 percent of seven crisis types until the early 1990s, but its share declines to 35 percent in the late 1990s. Debt crises become less frequent in the 1990s as well. In the 1980s, debt crises account for 15 percent, while their share declines to five percent in the late 1990s. On the other hand, solvency type banking crises increase their share to 17 percent in the late 1990s, and financial crises double their share in the late 1990s.

The decline in the relative importance of currency crises seems to be consistent with the developments of the exchanger rate regimes. Under the flexible exchange rate regime the risk of abrupt currency deprecation is less compared to the fixed exchange rate regime. In the past, many countries adopted fixed exchange rate and/or managed exchange rate regimes so that to prevent excess fluctuations of the currencies. According to the IMF (1997, p.79), in 1981 among 113 developing countries 57 countries had pegged exchange rate regimes, 10 countries had limited-flexibility exchange rate regimes and 15 countries had more flexible exchange rate regimes. In 1996, 45 countries had pegged exchange rate regimes, three countries had limited-flexibility exchange rate regimes and 52 countries had more flexible exchange rate regimes. The decline in the relative importance of currency crises is not only the share in total but also the absolute numbers. In 1981-1985 there were 146 currency crisis periods, while there were 61 currency crisis periods in 1996-2000. 
The more equal share of each type of crises in the late 1990s may suggest that the relationships between different crisis types become closer than the past. In other words, one crisis type tends to trigger other types of crises more often than the past.

Table 6: Composition of Crisis Periods of Each Crisis Type across Periods (Percent share in total)

\begin{tabular}{|c|c|c|c|c|c|c|c|c|c|c|}
\hline & \multicolumn{2}{|c|}{ 1981-1985 } & \multicolumn{2}{|c|}{ 1986-1990 } & \multicolumn{2}{|c|}{ 1991-1995 } & \multicolumn{2}{|c|}{$1996-2000$} & \multicolumn{2}{|c|}{$2001-20021 /$} \\
\hline & No." & Degree & No." & Degree & "No." & Degree & No." & Degree & No." & Degree \\
\hline $\begin{array}{c}\text { Banking } \\
\text { (Liquidity) }\end{array}$ & $7(21)$ & 7 & $6(10)$ & 6 & $11(13)$ & 10 & $14(24)$ & 12 & $5(3)$ & 6 \\
\hline $\begin{array}{l}\text { Banking } \\
\text { (Solvency) }\end{array}$ & $8(23)$ & 8 & $2(4)$ & 2 & $9(11)$ & 9 & $16(29)$ & 17 & $13(7)$ & 13 \\
\hline $\begin{array}{l}\text { Balance of } \\
\text { Payments }\end{array}$ & $3(8)$ & 3 & $2(3)$ & 2 & $1(1)$ & 1 & $6(10)$ & 6 & $16(9)$ & 16 \\
\hline Currency & $\begin{array}{c}51 \\
(146)\end{array}$ & 53 & $\begin{array}{c}62 \\
(101)\end{array}$ & 64 & $54(64)$ & 56 & $35(61)$ & 35 & 34 (19) & 36 \\
\hline Debt & $17(48)$ & 16 & $15(25)$ & 14 & $7(8)$ & 7 & $6(10)$ & 5 & $4(2)$ & 3 \\
\hline $\begin{array}{c}\text { Growth } \\
\text { Rate }\end{array}$ & $11(31)$ & 11 & $6(10)$ & 6 & $15(18)$ & 14 & $16(29)$ & 17 & $23(13)$ & 21 \\
\hline Financial & $2(7)$ & 2 & $6(9)$ & 6 & $3(3)$ & 3 & $7(13)$ & 8 & $5(3)$ & 5 \\
\hline Total & $\begin{array}{c}100 \\
(284)\end{array}$ & 100 & $\begin{array}{c}100 \\
(162)\end{array}$ & 100 & $\begin{array}{c}100 \\
(118)\end{array}$ & 100 & $\begin{array}{c}100 \\
(174)\end{array}$ & 100 & $\begin{array}{l}100 \\
(56)\end{array}$ & 100 \\
\hline
\end{tabular}

1/ Composition may depend on data availability, since some data in 2002 are not available

Note: Figures in brackets are the number of crisis periods

Source: Author

Source: Author

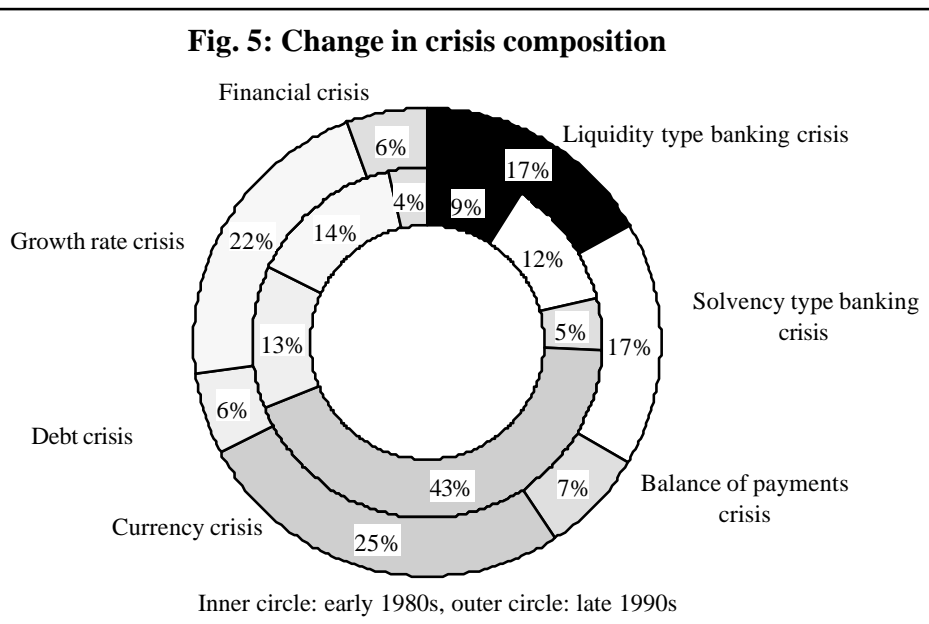

\subsubsection{Period}

The number of crisis periods and episodes declines until the early 1990s, but it increases again in the late 1990s (Table 7, Fig. 6). This is mainly due to the Asian crisis in 1997 and subsequent crises in Latin America in 1998. In the early 1980s, there are 19 crisis episodes in 15 emerging economies. Afterwards, the number of episodes declines to 14 in the late 1980s and seven in the early 1990s. However, the number of episodes increases to 12 in the late 1990s. The average degree of one crisis episode also increases in the late 1990s (Fig. 7). The average degree of each crisis episode is -22 in the early $1980 \mathrm{~s},-11$ in the late $1980 \mathrm{~s}$, 
and -13 in the early 1990s. As such, by the early 1990s, not only the number of crisis episodes falls but also the degree of each crisis declines. However, this trend reverses in the late 1990s. In addition to the increase in the number of crisis episodes, the degree of crisis increases mainly due to the depth of crises rather than their length.

Table 7: Crisis Identification on a Periodical Basis in Q1 1980-Q4 2002

\begin{tabular}{|c|c|c|c|c|c|c|c|c|}
\hline & \multicolumn{4}{|c|}{ Crisis Quarters (Periods) } & \multicolumn{4}{|c|}{ Crisis Episodes 1/ } \\
\hline & $\begin{array}{c}\text { No. of } \\
\text { quarters }\end{array}$ & $\begin{array}{l}\text { Ratio in } \\
\text { samples }\end{array}$ & $\begin{array}{c}\text { Total } \\
\text { degree } \\
2 /\end{array}$ & $\begin{array}{c}\text { Crisis } \\
\text { average } \\
\text { 3/ }\end{array}$ & $\begin{array}{c}\text { No. of } \\
\text { episodes }\end{array}$ & $\begin{array}{c}\text { No. of } \\
\text { quarters }\end{array}$ & $\begin{array}{c}\text { Total } \\
\text { degree } 2 /\end{array}$ & $\begin{array}{c}\text { Episode } \\
\text { average 3/ }\end{array}$ \\
\hline $1980-2002$ & 827 & $9.2 \%$ & $-2,121$ & -2.6 & 59 & 203 & $-1,130$ & -19 \\
\hline $1980-1990$ & 477 & $11.4 \%$ & $-1,212$ & -2.5 & 36 & 127 & -626 & -18 \\
\hline 1991-2002 & 350 & 7.4 & -909 & -2.6 & 23 & 76 & -504 & -21 \\
\hline 1981-1985 & 284 & $15.1 \%$ & -713 & -2.5 & 19 & 83 & -420 & -22 \\
\hline 1986-1990 & 162 & $8.3 \%$ & -421 & -2.6 & 14 & 33 & -157 & -11 \\
\hline 1991-1995 & 118 & $6.0 \%$ & -308 & -2.6 & 7 & 14 & -92 & -13 \\
\hline $1996-2000$ & 176 & $8.8 \%$ & -456 & -2.6 & 12 & 50 & -338 & -28 \\
\hline $2000-2002$ & 56 & $7.2 \%$ & -145 & -2.6 & 4 & 12 & -73 & -18 \\
\hline
\end{tabular}

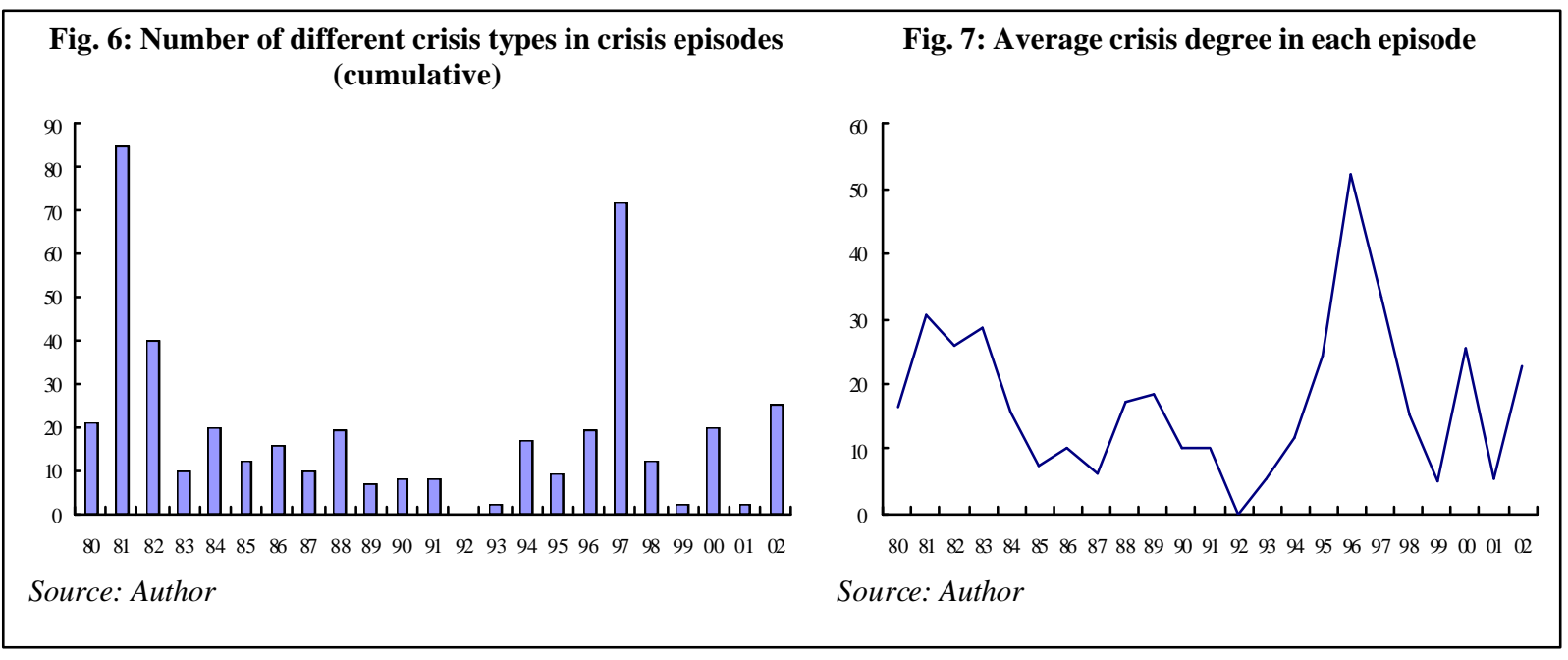

\section{Crisis Transmission Mechanism}

The crisis identification exercise suggests that the relationship between crisis types becomes closer in these days than the past. Existing crisis studies mainly deal with a few types of crises such as currency crises and banking crises. Growth rates are mainly used as a measurement of the degree of crises rather than as a separate type of crises. However, growth rates are not only be affected by other types of crises but also affect other crisis types in turn. Literature review regarding the relationships between crisis types provides rich ideas, though some relationships are rarely found. In theory, there are 42 relationships between seven different types of crises if bidirectional causalities are taken into account. However, only 12 relationships are explained in existing studies. 


\subsection{Literature Review}

\subsubsection{Balance of Payments Crises to Financial Crises}

Stoker (1995 in Kaminsky and Reinhart (1998, p.2)) states that "if not sterilized, this [the loss of reserves] will lead to a credit crunch, increased bankruptcies, and financial crisis."

\subsubsection{Balance of Payments Crises to Currency Crises}

Kaminsky and Reinhart (1998, p.2) state "as the current account deficit continues to widen, financial markets become convinced that the stabilization program is unsustainable, fueling an attack against the domestic currency."

\subsubsection{Banking Crises to Currency Crises}

Obstfeld (1994, in Glick and Hutchison (1999, p.3)) argues that "a weak banking sector may precipitate a currency crisis if rational speculators anticipate that policy makers will choose inflation over exchange rate stability in order to avoid bankruptcies and further strains on banking sector rather than endure the costs of defending domestic currency." Valasco (1987) and Calvo (1987) (in Glick and Hutchison (1999, p.3) argue that "a bank run can cause a currency attack if the increased liquidity associated with a government bailout of the banking system is inconsistent with a stable exchange rate." Gonzales-Hermosillo (1996, in Glick and Hutchison (1999, p.3)) shows that "a bank crisis may lead to a currency crisis in a poorly developed financial system where agents may substitute foreign assets for domestic assets." Kaufman (2000, p.13) argues that "banking problems may also ignite currency problems, particularly in smaller, open economies on fixed or semi-fixed exchange rate standards. If the banking and any accompanying macroeconomic and asset price bubble problems are sufficiently severe, domestic and foreign depositors at insolvent or near-insolvent banks are likely to shift their deposits to perceived safer banks, including foreign-owned domestically or non-domestically domiciled banks, possibly in foreign-currency denominated deposits. At the same time, other domestic and foreign investors are likely to shift their funds abroad, again partially or totally in foreign currency. Such capital outflows (run) exert downward pressure on the country's exchange rate."

\subsubsection{Banking Crises / Currency Crises to Growth Rate Crises}

Gupta, Mishra and Sahay (2001, pp.7-8) state that "if the banking sector is not sound or is already experiencing a crisis around the time of the currency crisis, the supply of credit to domestic firms is likely to

get disrupted. With devaluation adversely affecting the balance sheets of their clients and with a rise in non-performing loans, banks may roll back their lending activities or go bankrupt."

\subsubsection{Banking Crises to Growth Rate Crises}

Demirguc-Kunt and Detragiache (1997, p.2) assert that "banking crises disrupt the flow of credit to households and enterprises, reducing investment and consumption and possibly forcing viable firms into bankruptcy."

\subsubsection{Banking Crises to Financial Crises}

Demirguc-Kunt and Detragiache (1997, p.2) assert that "banking crisis may also jeopardize the functioning of the payments system and, by undermining confidence in domestic financial institutions, they may cause a decline in domestic saving and/or a large scale capital outflows."

\subsubsection{Currency Crises to Banking Crises}

Kaminsky and Reinhart (1998, p.2) conclude that "the peak of banking crisis most often comes after the currency crash, suggesting that existing problems were aggravated or new ones created by the high interest 
rates required to defend the exchange rate peg or the foreign exchange exposure of banks." Mishkin (1996 in Kaminsky and Reinhart (1998, p.2)) argues that "if a devaluation occurs, the position of banks could be weakened further if a large share of their liabilities is denominated in a foreign currency." Miller (1996 in

Glick and Hutchison (1999, p.3)) shows that "a speculative attack on a currency can lead to a bank crisis if deposit money is used to speculate in the foreign exchange market and banks are loomed up." Glick and Hutchison (1999, p.3) state "a currency shock can adversely alter the banking sector directly by causing a deterioration of bank balance sheets if the currency depreciates, or indirectly by causing the central bank to raise interest rates to defend the currency."

\subsubsection{Financial Crises to Banking Crises}

Kaminsky and Reinhart (1998, p.2) assert that "since the boom is usually financed by a surge in bank credit, as banks borrow abroad, when capital inflows become outflows and asset markets crash, the banking system caves in."

\subsubsection{Currency Crises to Debt Crises}

Gupta, Mishra and Sahay (2001, p.6) state that "when a large part of the liabilities of the domestic firms are denominated in foreign currency, a sudden devaluation leads to an overnight increase in their debt burden." Kaufman $(2000$, p.13) states that "currency crises characterized by a sharp depreciation in exchange rates are likely to increase both the burden of debt denominated in foreign currency to domestic borrowers and the probability of default on such debt."

\subsubsection{Debt Crises to Growth Rate Crises}

Gupta, Mishra and Sahay (2001, p.6) state that "this [debt burden due to currency devaluation] in turn, almost immediately impacts their balance sheet, and makes it virtually impossible for them to raise new loans to make debt repayments. The debt overhang can be expected to reduce aggregate investment and economic activities." Rodrik and Velasco (2000 in Gupta, Mishra and Sahay (2001, p.6)) argue that "difficulties in rolling over short-term debt during currency crises could squeeze the liquidity available within the economy and shrink the level of economic activities."

\subsubsection{Financial Crises to Growth Rate Crises}

Kaminsky (1999, p.7) argue that "capital flight has been shown to have caused an erosion of the tax base and a reduction in domestic investment..."

\subsubsection{Financial Crises to Currency Crises}

Kaminsky (1999, p.7) argue that "as it [capital flight] leads to a build up of gross foreign debt, it can fuel a currency crisis as foreign investors become doubtful about the ability and the will of the emerging economies to pay back."

\subsection{Data and Methodology}

Seven crisis types, in theory, produce 42 combinations of relationships, since the relationships are not unidirectional but bidirectional causality. In order to analyze the relationships, the standardized scores obtained for the crisis identification exercise are used. First, the correlation analysis of seven crisis types in 15 countries is conducted to capture a broad picture of the relationships. Although correlation coefficients are useful, they cannot clarify causality between crisis indicators.

Afterwards, Grander causality test is conducted for five East Asian countries (Indonesia, Korea, Malaysia, 
the Philippines and Thailand), as these countries were severely affected by the Asian crisis in the late 1990s. It should be noted that "the Granger test is just a statistical test based not on a specific theory of causation but based on the ability of the equation to predict better the dependent variable. Furthermore, the validity of the test depends on the order of the VAR [Vector Autoregression] model and on the stationary or not of the variable." (Seddighi et. al. (2000, p.311) "One set of variables, $x$, is said to Granger-cause another set, $y$, if adding past value of $x$ in a regression equation for predicting $y$, which already includes all past values of $y$ as regressions, improve the predictive power of the equation in the sense that it reduces the mean squared forecast error." (Buiter, 1984, p.160) Unit root tests should be conducted first to check whether the standardized scores are stationary.

\subsection{Result}

\subsubsection{Correlation Coefficients}

The results of the correlation analysis (Table 8) show considerable diversifications in terms of the number of significant relationships across countries and crisis types. In total, there are 138 significant relationships with 5 percent confidence level or 46 percent of total samples. Of which, 107 relationships are positive and 29 relationships are negative. Positive significant relations indicate that two crisis types tend to move together to the same direction.

On a country basis, East Asian countries (Indonesia, Korea, Malaysia, the Philippines and Thailand) have more positive significant relationships than other countries. For example, the Philippines has 15 significant relations and of which 13 are positive, and Thailand has 13 significant relations and all of them are positive. On the other hand, Venezuela has only three significant relationships and one is negative. In Brazil, India and Kenya, negative significant relationships are five or higher than the numbers of positive relationships.

With regard to the combination of crisis types, the relationship between liquidity type banking crises and currency crises is significantly correlated in 11 countries and of them 10 are positive. And the relationship between currency crises and growth rate crises is positively correlated in 10 countries. These suggest that liquidity type banking crises tends to be associated with currency crises (Section 3.1.3 and 3.1.7 above) and currency crises tend to be associated with growth rate crises, although the causality is not clarified. Moreover, these results imply, for example, that liquidity type banking crises and currency crises are susceptible to the same factors such as political instability. For example, if political instability leads to currency depreciation, people may want to keep cash in hand for emergency. On the other hand, the relationship between debt crises and financial crises is significant in only three countries and all of them are negative. The negative relationship does not necessarily seem illogical. If debt crises are caused by the increase in debt outstanding rather than the decline in exports, this implies capital (in the form of borrowing) flows into a country, and this is inconsistent with financial crises which show capital flight. The negative significant relationships are important, too. For example, if a country tries to defend the currency by using its international reserves and succeed, an appreciation of the currency could be associated with the decline in international reserves. 
Table 8: Correlation Coefficients Matrix (1980-2002)

\begin{tabular}{|c|c|c|c|c|c|c|c|c|c|c|c|c|c|c|c|c|c|c|c|c|c|}
\hline & AR & BR & COM & IN & IND & KE & KO & MA & ME & $\mathbf{P H}$ & CE & TH & TU & UR & VE & (A) & (B) & (C) & (D) & (E) & (F) \\
\hline LIQ-SOL & & & & ${ }^{* *}(-)$ & & ${ }^{* *}(-)$ & & & & ** & & & & $\star \star$ & & 4 & $27 \%$ & 2 & $13 \%$ & 2 & $13 \%$ \\
\hline LIQ-BOP & ** & ${ }^{* *}(-)$ & ** & & ${ }^{*}(-)$ & & & * & & ** & & ** & & ** & & 8 & $53 \%$ & 6 & $40 \%$ & 2 & $13 \%$ \\
\hline LIQ-CUR & * & ** & ** & ${ }^{* *}(-)$ & ** & & ** & ** & ** & ** & & * & & ** & & 11 & $73 \%$ & 10 & $67 \%$ & 1 & $7 \%$ \\
\hline LIQ-DEB & ** & & ** & & *夫 & & ** & $* *$ & & $\star \star$ & ${ }^{* *}(-)$ & ** & & & & 8 & $53 \%$ & 7 & $47 \%$ & 1 & $7 \%$ \\
\hline \begin{tabular}{|l|} 
LIQ-GRO \\
\end{tabular} & ** & & ** & ${ }^{*}(-)$ & & $*(-)$ & & ** & & ** & & ** & & ** & & 8 & $53 \%$ & 6 & $40 \%$ & 2 & $13 \%$ \\
\hline LIQ-FIN & ** & & & & & n.a & & ** & ** & ${ }^{* *}(-)$ & & & & n.a & & 4 & $31 \%$ & 3 & $23 \%$ & 1 & $8 \%$ \\
\hline SOL-BOP & & ** & & & & ${ }^{*}(-)$ & & & & & & & * & * & & 4 & $27 \%$ & 3 & $20 \%$ & 1 & $7 \%$ \\
\hline SOL-CUR & ${ }^{* *}(-)$ & ${ }^{* *}(-)$ & & ** & & & ** & & & * & & ** & * & & & 7 & $47 \%$ & 5 & $33 \%$ & 2 & $13 \%$ \\
\hline SOL-DEB & & & & ${ }^{* *}(-)$ & & $*(-)$ & ** & ${ }^{* *}(-)$ & ${ }^{* *}(-)$ & * & & & & & $\star *$ & 7 & $47 \%$ & 3 & $20 \%$ & 4 & $27 \%$ \\
\hline SOL-GRO & & & ${ }^{* *}(-)$ & $\star *$ & ** & & & $*(-)$ & ** & & ** & & & ${ }^{* *}(-)$ & $* *(-)$ & 8 & $53 \%$ & 4 & $27 \%$ & 4 & $27 \%$ \\
\hline SOL-FIN & & ${ }^{*}(-)$ & ** & & & n.a & & ${ }^{* *}(-)$ & ** & ${ }^{\star *}(-)$ & *夫 & & & n.a & & 6 & $46 \%$ & 3 & $23 \%$ & 3 & $23 \%$ \\
\hline BOP-CUR & & ${ }^{* *}(-)$ & & & & ${ }^{*}(-)$ & ** & & * & * & & & ** & ** & & 7 & $47 \%$ & 5 & $33 \%$ & 2 & $13 \%$ \\
\hline BOP-DEB & & & ** & & & & ** & & & & & ** & & & ** & 4 & $27 \%$ & 4 & $27 \%$ & 0 & $0 \%$ \\
\hline \begin{tabular}{|l|} 
BOP-GRO \\
\end{tabular} & ** & & ** & & ** & & * & & * & & * & ** & & ** & & 8 & $53 \%$ & 8 & $53 \%$ & 0 & $0 \%$ \\
\hline BOP-FIN & ** & & & & & n.a & & ${ }^{* *}(-)$ & & * & & * & ** & n.a & & 5 & $38 \%$ & 4 & $31 \%$ & 1 & $8 \%$ \\
\hline CUR-DEB & & * & & & ** & * & ** & 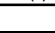 & ** & *夫 & & * & & & & 7 & $47 \%$ & 7 & $47 \%$ & 0 & $0 \%$ \\
\hline CUR-GRO & & & ** & * & $\star \star$ & ** & ** & ** & * & $\star \star$ & & $\star \star *$ & ** & & & 10 & $67 \%$ & 10 & $67 \%$ & 0 & $0 \%$ \\
\hline CUR-FIN & & & & & & n.a & & ** & ** & & & ** & * & n.a & & 4 & $31 \%$ & 4 & $31 \%$ & 0 & $0 \%$ \\
\hline DEB-GRO & & *(-) & *夫 & & & & ** & ** & * & ** & *夫 & ** & & ** & & 9 & $60 \%$ & 8 & $53 \%$ & 1 & $7 \%$ \\
\hline DEB-FIN & & & ${ }^{* *}(-)$ & ${ }^{*}(-)$ & & n.a & & & & & ${ }^{* *}(-)$ & & & n.a & & 3 & $23 \%$ & 0 & $0 \%$ & 3 & $23 \%$ \\
\hline GRO-FIN & ** & & ${ }^{* *}(-)$ & & & n.a & & & ** & * & & ** & ** & n.a & & 6 & $46 \%$ & 5 & $38 \%$ & 1 & $8 \%$ \\
\hline $\begin{array}{l}\text { No. of } \\
\text { significant (A) }\end{array}$ & 9 & 8 & 12 & 8 & 7 & 7 & 10 & 12 & 12 & 15 & 6 & 13 & 7 & 9 & 3 & 138 & $46 \%$ & - & - & - & - \\
\hline \begin{tabular}{|l|}
$(\%)$ of total \\
samples (B)
\end{tabular} & $43 \%$ & $38 \%$ & $57 \%$ & $38 \%$ & $33 \%$ & $47 \%$ & $48 \%$ & $57 \%$ & $57 \%$ & $71 \%$ & $29 \%$ & $62 \%$ & $33 \%$ & $60 \%$ & $14 \%$ & $46 \%$ & - & - & - & - & - \\
\hline $\begin{array}{l}\text { No. of positive } \\
\text { significant (C) }\end{array}$ & 8 & 3 & 9 & 3 & 6 & 2 & 10 & 8 & 11 & 13 & 4 & 13 & 7 & 8 & 2 & - & - & 107 & $35 \%$ & - & - \\
\hline $\begin{array}{l}\text { (\%) of total } \\
\text { samples (D) }\end{array}$ & $38 \%$ & $14 \%$ & $43 \%$ & $14 \%$ & $29 \%$ & $13 \%$ & $48 \%$ & $38 \%$ & $52 \%$ & $62 \%$ & $19 \%$ & $62 \%$ & $33 \%$ & $53 \%$ & $10 \%$ & - & - & $35 \%$ & - & - & - \\
\hline $\begin{array}{l}\text { No. of negative } \\
\text { significant (E) }\end{array}$ & 1 & 5 & 3 & 5 & 1 & 5 & 0 & 4 & 1 & 2 & 2 & 0 & 0 & 1 & 1 & - & - & - & - & 31 & $10 \%$ \\
\hline $\begin{array}{l}\% \text { of total } \\
\text { samples (F) }\end{array}$ & $5 \%$ & $24 \%$ & $14 \%$ & $24 \%$ & $5 \%$ & $33 \%$ & $0 \%$ & $19 \%$ & $5 \%$ & $10 \%$ & $10 \%$ & $0 \%$ & $0 \%$ & $7 \%$ & $5 \%$ & - & - & - & - & $10 \%$ & - \\
\hline
\end{tabular}

Note: (*) and (**) indicate statistical significance at a level of 5 percent and 1 percent, (-) denotes the relation is negatively significant

n.a. denotes data are not available

Country: AR-Argentina, BR-Brazil, COM-Colombia, IN-India, IND-Indonesia, KE-Kenya, KO-Korea, MA-Malaysia, ME-Mexico, PH-Philippines, CE-Sri Lanka, TH-Thailand, TU-Turkey, UR-Uruguay, VE-Venezuela

Crisis types: LIQ-Liquidity type banking crises, SOL-Solvency type banking crises, BOP-Balance of payments crises, CUR-Currency crises, DEB-Debt crises, GRO-Growth rate crises, FIN-Financial crises

Source: Author

\subsubsection{Granger Causality of Five East Asian Countries}

Although the correlation coefficients are informative, causality cannot be clarified. For example, regarding the relationship between liquidity type banking crises and currency crises, which one comes first and/or whether there is any bidirectional relationship is important. The causality analysis can contribute policy recommendations on how to prevent the spread of crises. In order to develop the analysis on the relationships between crisis types, Granger causality test is carried out for the five Asian countries. The five East Asian countries show relatively closer relationships than others in the correlation coefficient analysis, and Granger causality test is expected to crystallize the crisis transmission mechanisms of the Asian crisis.

The order of integration of variables should be examined first, since non-stationary variables cause spurious regressions (Matuura and McKenzie (2001, p.243). The Augmented Dickey-Fuller test (ADF) is used for this purpose. ADF test procedures follow (i) to implement both with intercept and, trend and intercept, (ii) to select the lag period based on the minimum AIC (Akaike's Minimum Information Criteria), and (iii) to start from the level and proceed to the first difference if null-hypothesis is not rejected in the level (Matuura and McKenzie, 2001, p.241). If the null-hypothesis that a time series is non-stationary is accepted 
in levels, the same procedure is applied for first differentiated data. On the other hand, if the null-hypothesis of non-stationary is rejected, the time series is integrated of order of zero (I (0)) in case variables are in level or one (I (1)) in case variables are in first differenced form. For ADF test, this section adopts the following five steps, and the results of ADF test are shown in Table 9.

(i) Test the lag periods between one and four;

(ii) Test both AIC and Schwarz Criterion (SC) for the lag selection;

(iii) Test with non, intercept and, intercept and trend;

(iv) Choose a lag period with minimum AIC and SC;

(v) Compare the results with one, five and ten percent critical values.

Table 9: ADF test for Five East Asian Countries (1980-2002)

\begin{tabular}{|c|c|c|c|c|c|}
\hline & Indonesia & Korea & Malaysia & Philippines & Thailand \\
\hline Liquidity type banking & $\mathrm{I}(0)$ & I (1) & I (1) & $\mathrm{I}(1)$ & $\mathrm{I}(1)$ \\
\hline Solvency type banking & $\mathrm{I}(0)$ & I (1) & I (1) & $\mathrm{I}(0)$ & $\mathrm{I}(1)$ \\
\hline Balance of payments & $\mathrm{I}(0)$ & $\mathrm{I}(0)$ & $\mathrm{I}(0)$ & $\mathrm{I}(0)$ & I (1) \\
\hline Currency & $\mathrm{I}(0)$ & $\mathrm{I}(0)$ & $\mathrm{I}(0)$ & $\mathrm{I}(0)$ & $\mathrm{I}(0)$ \\
\hline Debt & $\mathrm{I}(0)$ & $\mathrm{I}(1)$ & $\mathrm{I}(0)$ & I (1) & I (1) \\
\hline Growth rate & $\mathrm{I}(0)$ & $\mathrm{I}(0)$ & $\mathrm{I}(0)$ & $\mathrm{I}(0)$ & $\mathrm{I}(0)$ \\
\hline Financial & $\mathrm{I}(0)$ & $\mathrm{I}(0)$ & I (0) & I (0) & $\mathrm{I}(0)$ \\
\hline
\end{tabular}

Note: I (0) denotes the order of integration is zero, and I (1) denotes the order of integration is one

Source: Author

Granger causality test finds twenty-five significant relationships with five percent confidence level between crisis types (Table 10) or 12 percent of total number of relationships of 210 (42 relationships in five countries) shows Granger causality. On a crisis basis, eight relationships or one-third of total start from currency crises. Although the sample period covers since 1980, this observation is consistent with the widely-shared view that the Asian crisis was triggered from the abrupt currency depreciation. Also there are five significant relationships starting from balance of payments crises. However, there are only one significant relationship starting from growth rate crises, and this implies that growth rate crises do not tend to lead to other types of crises. On a result basis or which types of crises are affected more than others, each crisis is almost equally affected. Growth rate crises are the result in five relationships, and solvency type banking crises, balance of payments crises, currency crises and debt crises are the results in three relationships. On a country basis, Indonesia has eight significant Granger causality relationships, followed by Korea (7). On the other hand, Malaysia and the Philippines have three significant Granger causality relationships. There are only two bidirectional relationships. One is the balance of payments and currency crises in Indonesia. The other is currency crises and financial crises in Korea. 
Table 10: Granger Causality Test of Five Asian Countries

\begin{tabular}{|c|c|c|c|c|c|c|c|}
\hline & & Indonesia & Korea & Malaysia & Philippines & Thailand & Total \\
\hline 1 & LIQ? SOL & & & & & & \\
\hline 2 & LIQ? BOP & $* *$ & & & & & $1(1)$ \\
\hline 3 & LIQ? CUR & & & & & & \\
\hline 4 & LIQ? DEB & & & & & & \\
\hline 5 & LIQ? GRO & & $*$ & & & & $1(0)$ \\
\hline 6 & LIQ? FIN & $*$ & & & & & $1(0)$ \\
\hline 7 & SOL? LIQ & & $*$ & $*$ & & & $2(0)$ \\
\hline 8 & SOL? BOP & & & & & & \\
\hline 9 & SOL? CUR & & & & & & \\
\hline 10 & SOL? DEB & $* *$ & & & & & $1(1)$ \\
\hline 11 & SOL? GRO & & & & & & \\
\hline 12 & SOL? FIN & & & & & & \\
\hline '"13" & BOP? LIQ & $* *$ & & & * & & $2(1)$ \\
\hline 14 & BOP? SOL & & & & & & \\
\hline 15 & BOP? CUR & $*$ & & & & $*$ & $2(0)$ \\
\hline 16 & BOP? DEB & & & & & & \\
\hline 17 & BOP? GRO & & & $* *$ & & & $1(1)$ \\
\hline 18 & BOP? FIN & & & & & & \\
\hline "'19" & CUR?'LIQ" & & & & & & \\
\hline 20 & CUR? SOL & & $* *$ & & $* *$ & & $2(2)$ \\
\hline 21 & CUR? BOP & $* *$ & $*$ & & & & $2(1)$ \\
\hline 22 & CUR? DEB & $*$ & & $* *$ & & & $2(1)$ \\
\hline 23 & CUR? GRO & & & & $* *$ & $*$ & $2(1)$ \\
\hline 24 & CUR? FIN & & $* *$ & & & & $1(1)$ \\
\hline 25 & DEB? LIQ & & & & & & \\
\hline 26 & DEB? SOL & & $*$ & & & & $1(0)$ \\
\hline 27 & DEB? BOP & & & & & & \\
\hline 28 & DEB? CUR & & & & & & \\
\hline 29 & DEB? GRO & & & & & & \\
\hline 30 & DEB? FIN & & & & & $*$ & $1(0)$ \\
\hline 31 & GRO? LIQ & & & & & & \\
\hline 32 & GRO? SOL & & & & & & \\
\hline 33 & GRO? BOP & & & & & & \\
\hline 34 & GRO? CUR & & & & & & \\
\hline 35 & GRO? DEB & & & & & & \\
\hline 36 & GRO? FIN & & & & & $* *$ & $1(1)$ \\
\hline 37 & FIN? LIQ & & & & & & \\
\hline 38 & FIN? SOL & & & & & & \\
\hline 39 & FIN? BOP & & & & & & \\
\hline 40 & FIN? CUR & & $*$ & & & & $1(0)$ \\
\hline 41 & FIN? DEB & & & & & & \\
\hline 42 & FIN? GRO & $* *$ & & & & & $1(1)$ \\
\hline & Total & $8(5)$ & $7(2)$ & $3(2)$ & $3(2)$ & $4(1)$ & $25(12)$ \\
\hline
\end{tabular}

Note: $(*)$ and $(* *)$ indicate statistical significance at a level of 5 percent and 1 percent,

LIQ-Liquidity type banking crises, SOL-Solvency type banking crises, BOP-Balance of payments crises, CUR-Currency crises, DEB-Debt crises, GRO-Growth rate crises, FIN-Financial crises

Figures show the number of Granger causality with 5 percent confidence level, and those in brackets show significant Granger causality with 1 percent confidence level.

Source: Author

\section{Conclusion}

This paper has two objectives. The first is to identify crisis periods and episodes consistently. The second is to analyze the relationships between crisis types. The motivation is that despite the volume of 
development economics literature on crises, the identification of crisis periods and crisis episodes is opaque. There are several reasons. For example, the definitions of each type of crisis differ in each study and hence different identifications are produced. Inconsistent crisis identifications may have negative consequences on crisis related studies, since studies on crisis prevention (such as the early warning system) and crisis management treat crisis episodes as dependent variables. Consequently, inconsistent identification may lead to inconsistent conclusions even if the same analytical framework is applied.

This paper examines seven crisis types such as liquidity type banking crises, solvency type banking crises, balance of payments crises, debt crises, growth rate crises and financial crises. The number of crisis types is higher than most existing studies, since one of the most important characteristics of recent crises is multidimensionality in which different types of crises occur simultaneously and/or affect each other within a short period. There are 15 sample countries, and the sample period is Q1 1980-Q4 2002. Countries are selected based on frequency in crisis studies and data availability. Quarterly basis analyses are conducted to capture crisis developments more accurately than annual ones.

Crisis periods are identified based on standardized scores, since one of the most important features of crises is an 'abrupt' change in economic indicators, and crisis episodes are further identified based on two sets of conditions to exclude false signals of crisis period identifications. One is that at least two crisis types are required to pinpoint the start of a crisis episode. The other is that three quarter window periods are introduced to pinpoint the end of a crisis episode.

The main findings from crisis identification are:

(i) Fifty-nine crisis episodes are identified, though the frequency varies in each country. Turkey has seven crisis episodes, while the Philippines and Malaysia have only two crisis episodes;

(ii) Currency crises occur most frequently in crisis episodes or 85 percent of crisis episodes are associated with currency crises;

(iii) The frequency of currency crises declines in the late 1990s. The share of currency crises in total crisis periods declines from 50 percent in the early 1980s to 35 percent in the late 1990s. The more equal distribution of each crisis suggests the multidimensional aspect of recent crises;

(iv) The number of crisis episodes declines by the early 1990s, but it increases in the late 1990s due to the Asian crisis and Latin America crisis. The severity of crisis measured by the depth (i.e. deviation from the crisis threshold) and length is the severest in the late 1990s.

The relationships and transmission mechanisms are analyzed based on correlation coefficients for all 15 countries. Afterwards, the Granger causality test is conducted for five Asian countries (Indonesia, Korea, Malaysia, the Philippines and Thailand). The main findings are:

(i) The East Asian countries have higher number of positive relationships between crisis types than other countries;

(ii) The relationship between liquidity type banking crises and currency crises is positive in eleven countries out of 15 followed by the 10 relationships between currency crises and growth rate crises. These result suggests that currency crises tend to be associated with liquidity type banking crises and growth rate crises;

(iii) Granger causality test of the five Asian countries finds that currency crises tend to trigger other types of crises, and the bidirectional relationships are rarely observed; 
Policy recommendations based on the findings are:

(i) Since characteristics of cris is are not identical across countries and periods, policy makers should pay more attention to changing characteristics of crises;

(ii) As the interactions between crises seem to be closer in recent periods, policy makers should prepare policies to mitigate risks of crisis diffusion once one type of crisis is observed. For example, when currency crises are observed, policy makers should assess the risk of the liquidity type banking crises;

(iii) As currency crises tend to lead to other crisis types, exchange rate management is essential. However, recent experiences such as Indonesia in 1998 and Argentina in 2002 suggest that once sharp currency depreciation starts it is difficult to stop the momentum. Therefore, policy makers should be aware of the importance of exchange rate policies even in non-crisis periods.

\section{Notes}

(1) Sachs (1998), Aziz et al (2000), and IMF (1998) also use the same conceptual definition. In addition, Sachs (1998, p.248) explains banking crises as "commercial banks abruptly lose the ability to roll over market instrument."

(2) For example, Glick and Hutchison (1999), Kaminsky and Reinhart (1998) and Aziz et al. (2000) and Ahluwalia (2000) take this position.

(3) Aziz et al (2000, p.6) and IMF (1998, p.75) use the same conceptual definition

(4) Glick and Hutchison (1999), Kaminsky and Reinhart (1998), Aziz, Caramazza and Salgado (2000), Moreno and Trehan (2000), Esquivel and Larrain (1998), Ahluwalia (2000), Eichengreen, Rose and Wyplosz(1997), Caramazza, Ricci, and Salgado (2000), Osband and Rijckeghem (2000)

(5) In order to verify that gross reserve growth rates are a better indicator than the reserve to imports ratio, a separate analysis is conducted. The analysis shows the ratio cannot well capture widely recognized balance of payments episodes such as the Argentina crisis in 2001-02.

(6) Esquivel and Larrain (1998) take the same position

(7) Aziz et al (2000, p.6) take the same position

(8) The 15 countries are same as the ones used in later in this chapter

(9) The identification also depends on the choices of the threshold and sample periods

\section{References}

Ahluwalia, Pavan. 2000. "Discriminating Contagion: An Alternative Explanation of Contagious Currency Crises in Emerging Markets" IMF Working Paper WP/00/14

Ajayi, S. Ibi. 1997. "An Analysis of External Debt and Capital Flight in the Severely Indebted Low Income Countries in Sub-Saharan Africa" IMF Working Paper WP/97/68

Aziz, Jahangir, Francesco Caramazza and Ranil Salgado (2000) "Currency Crises: In Search of Common Elements" IMF Working Paper WP/00/67

Boyd John, Pedro Gomis, Sungkyu Kwak, and Bruce Smith. 2000. "A User's Guide to Banking Crises" Conference Paper, Deposit Insurance Conference

Bruno, Michael. 1996. Deep Crises and Reform: What Have We Learned? Washington: World Bank

Caprio, Gerard Jr. 1998. Banking on Crises: Expensive Lessons from Recent Financial Crises. Washington: World Bank

Caprio, Gerard Jr. and Daniela Klingebiel. 1996. "Bank Insolvencies: Cross Country Experience" IMF Policy Research Working Paper 1620 
Caramazza, Francesco, Luca Ricci, and Ranil Salgado. 2000. "Trade and Financial Contagion in Currency Cris es" IMF Working Paper WP/00/55

Caves, Richard E., Jeffery A. Frankel and Ronald W. Jones. 1996. World Trade and Payments: An Introduction. New York: HarperCollins College Publishers, New York

Demirguc-Kunt, Asli and Enrica Detragiache. 1997 The Determinant of Banking Crises: Evidence from Developed and Developing Countries. Washington: World Bank

Demirguc-Kunt, Asli and Enrica Detragiache. 1998. "Financial Liberalization and Financial Fragility" IMF Working Paper $98 / 83$

Demirguc-Kunt, Asli and Enrica Detragiache. 2000. "Does Deposit Insurance Increase Banking System Fragility?" IMF Working Paper WP/00/3

Demirguc-Kunt, Asli, Enrica Detragiache and Poonam Gupta. 2000. Inside the Crisis: An Empirical Analysis of Banking Systems in Distress. Washington: World Bank

Detragiache, Enrica and Antonio Spilimbergo. 2001. "Crises and Liquidity: Evidence and Interpretation" IMF Working Paper WP/01/2

Dornbusch, Rudier. 1989 Debt Problems and the World Macroeconomy. in Sachs, Jeffery D. (Eds.)

Eichengreen Barry, Andrew Rose and Charles Wyplosz 1997. "Contagious Currency Crises" NBER Working Paper 5681

Esquivel, Gerard and Felipe Larrain. 1998. "Explaining Currency Crises" Development Discussion Paper No.666 November 1998, Harvard Institution for International Development

Frank, Jeffery A. and Andrew K. Rose. 1996. "Currency Crashes in Emerging Markets: Empirical Indicators" (http://haas.berkeley.edu/ arose/Ccrash.pdf)

Frydl, Edward J. 1999. "The Length and Cost of Banking Crises" IMF Working Paper 99/30

Glick, Reuven and Michael Hutchison. 1999. "Banking and Currency Crises: How Common Are Twins?" Center for Pacific Basin Monetary and Economic Studies, Economic Research Department, Federal Reserve Bank of San Francisco Working Paper PB99-07

Goldfajn, Ilan and Poonam Gupta. 1999. "Does Monetary Policy Stabilize the Exchange Rate Following a Currency Crisis?" IMF Working Paper WP/99/42

Gupta, Poonam, Deepak Mishra and Ratna Sahay. 2001. "Output Response to Currency Crises" IMF Working Paper WP/03/230

Hardy, Daniel C. and Ceyla Pazarbasioglu. 1998. "Leading Indicators of Banking Crises: Was Asia Different?" IMF Working Paper 98/91

Hoggarth, Glenn, Ricardo Reis and Victoria Saporta. 2002. "Costs of Banking System Instability: Some Empirical Evidence" Journal of Banking and Finance 26 (2002) 825-855

Honohan and Klingebiel. 2002. "The Fiscal Cost Implications of an Accommodating Approach to Banking Crises" Journal of Banking and Finance 27 No.8 (2003) pp.1539-60

Hutchison, Michael and Ilan Neuberger. 2002. "How Bad Are Twins? Output Costs of Currency and Banking Crises" Center for Pacific Basin Monetary and Economic Studies, Economic Research Department, Federal Reserve Bank of San Francisco Working Paper PB02-02 Pacific

IMF. 1997. World Economic Outlook 1997. Washington: IMF

IMF. 1998. World Economic Outlook May 1998. Washington: IMF

IMF. 2000. Debt-and Reserve-Related Indicators of External Vulnerability. Washington: IMF

IMF. 2003. International Financial Statistics October 2003. Washington: IMF

Kahler, Miles. 1998. (Eds.) Capital Flows and Financial Crises. Manchester: Manchester University Press

Kaminsky, Graciela L. 1999. "Currency and Banking Crises: The Early Warnings of Distress" IMF Working Paper WP/99/178

Kaminsky, Graciela L. and Carmen L. Reinhart. 1998. "The Twin Crises: The Causes of Banking and Balance-of-Payments Problems" Forthcoming in American Economic Reviews

Kaufman, Daniel 2000. "Banking and Currency Crises and Systemic Risk: Lessons from Recent Events" Federal Reserve Bank of Chicago

Krugman, Paul R. and Maurice Obstfeld. 1997. International Economics: Theory and Policy fifth edition. Massachusetts : Addison-Wesley Publishing Company

Kumar, Manmohan S., Paul Masson and Marcus Miller 2000. "Global Financial Crises: Institutions and Incentives" IMF Working Paper WP/00/105

Lindsey, Charles W. 1984. "Economic Crisis in the Philippines" Asian Survey, Volume 24, Issue 12 (Dec., 
1984) pp.1185-1208

Loungani, Prakash and Paolo Mauro. 2001. "Capital Flight from Russia" The World Economy 2001 Volume 24, Issue 5

Matsuura, Katsumi, and Colin McKenzie. 2001. Eviews ni yoru Keiryo-Keizaigaku (Econometrics with Eviews) Tokyo: Toyo-Keizai Sinposya

Mehrez, Gil and Daniel Kaufman. 2000. "Transparency, Liberalization and Banking Crises" World Bank

Moreno, Ramon and Bharat Trehan. 2000. "Common Shocks and Currency Crises" Federal Reserve Bank of San Francisco

Non-Aligned Movement Ad Hoc Advisory Group of Experts on Debt. 1994. The Continuing Debt Crisis of the Developing Countries. Jakarta: Non-Aligned Movement Ad Hoc Advisory Group of Experts on Debt

Osband, Kent and Caroline Van Rijckeghem. 2000. "Safety from Currency Crashes" IMF staff papers Vol.47, No. 2

Sachs, Jeffery D. (Eds.) 1989. Developing Country Debt and the World Economy. Chicago: The University of Chicago Press

Sachs, Jeffery D. 1998. Alternative Approaches to Financial Crises in Emerging Markets in Kahler, Miles (Eds.)

Sachs, Jeffery D. and Wing Thye Woo. 2000. Understanding the Asian Financial Crisis in Woo, Wing Thye, Jeffery D. Sachs and Klans Schwab (Eds.)

Seddighi, H. K. A. Lawler and A. V. Katos. 2000 Econometrics: A Practical Approach. Routledge: London

Thirlwall, A. P. 1999 Growth and Development $6^{\text {th }}$ Edition. London: Macmillan Press

Wonnacott, Thomas H. and Ronald J. Wonnacott. 1990 Introductory Statistics for Business and Statistics Fourth Edition New York: John Wiley \& Sons

Woo, Wing Thye, Jeffery D. Sachs and Klans Schwab. (Eds.) 2000. The Asian Financial Crisis: Lessons for A Resilient Asia. London: The MIT Press

World Bank (2003) World Development Indicators 2003. Washington: World Bank 